\title{
Socioeconomic and racial/ethnic factors affecting non-fatal medically attended injury rates in US children
}

\author{
Mary D Overpeck, Diane H Jones, Ann C Trumble, Peter C Scheidt, Polly E Bijur
}

\begin{abstract}
Objective-Using a representative survey of US children, the purpose was to evaluate separate effects of socioeconomic and racial/ethnic factors, including access to care, on medically attended non-fatal injury rates.
\end{abstract}

Methods-Multivariate linear regression models were used to determine associations between injuries and health care coverage (insurance or Medicaid), having a place to go for care, race/ethnicity, maternal education, number of adults and children in the household, poverty, and urbanicity. The 1988 Child Health Supplement to the National Health Interview Survey included questions on medically attended injuries, and their cause, location, and effects on the child. Injury categories included total, consequential, occurrence at home or school, falls, and being struck or cut.

Results-Lack of health care coverage was consistently associated with lower medically attended injury rates in non-Hispanic blacks or whites and MexicanAmericans, but affected total rates for each group differently due to unequal distribution of health care coverage. Injuries occurred about $40 \%$ more frequently to children and adolescents living in single adult households compared with two adult homes for all injury categories except for injuries occurring at school.

Epidemiology Branch, National Institute of Child

Health and Human

Development,

6100 Executive Blvd,

Bethesda, MD 20892 ,

USA

MD Overpeck

AC Trumble

Emory University, Atlanta, Georgia DH Jones

Department of

Pediatrics, George

Washington School

of Medicine,

Washington, DC

PC Scheidt

Department of

Pediatrics,

Epidemiology and

Social Medicine,

Albert Einstein

College of Medicine,

Bronx, New York

PE Bijur

Correspondence to: Dr Overpeck.
Conclusions-Preventive interventions targeted to specific populations based on assumptions that poverty, lack of education, or minority status result in greater risks for injuries require a closer look. Efficient targeting should address underlying factors such as differences in exposures and environments associated with single adult homes or recreational activities. Data sources used to target high risk populations for interventions need to ad-

(Injury Prevention 1997; 3: 272 - 276)

Keywords: non-fatal injury; race/ethnicity; socioeconomics; access to care; parents.

Recent analyses of US data on non-fatal medically attended injury rates among adults and children have shown increased risks reported for higher income families, for children of mothers who are married or have higher education, and for whites compared with blacks. ${ }^{1-5}$ The racial findings are supdress bias due to access to care. ported by a national physician office based survey of all ages showing higher injury visft rates for whites than blacks. ${ }^{6}$ While these findings suggest differences due to access to medical care, similar differences occur for both medically attended and unattended activing restricting injury rates as reported by tho National Health Interview Survey (NHIS) which is the primary source of nonfatal injufy rates for the US. ${ }^{7}$ The association between race and non-fatal injuries is inconsistent with expectations based on fatal injury rates whic $\vec{b}$ are generally higher for black adolescents and children than for white. ${ }^{8-10}$ Studies used efficiently target preventive interventions neegl better discrimination among population factors that may affect risks.

Many studies show poverty to be associated with higher fatal and hospitalized injug risks, ${ }^{911-13}$ although recent local area research shows higher non-fatal risks may disappe after control for access to care and other socio factors related to poverty. ${ }^{14-16}$ Using a natio ally representative survey of children, Chifg Health Supplement (CHS) to the NHIS, out purpose is to identify underlying family socioeconomic risk factors amenable to targe ing for preventive intervention after adjustmen for access to care.

A recent international comparison of meds cally attended non-fatal injury rates in a scho\&l based study of young adolescents showed am extremely wide range across 24 developed countries in Europe and elsewhere. ${ }^{17}$ Injuty location was presented to demonstrate the family and school context in which evengs occurred to address the focus for preventio The authors cautioned about comparing dis ferences in rates among countries due to availability and utilization of medical service and the extent to which people define an injury as requiring medical attention.

Some factors that affect the propensity seek treatment for acute conditions include health insurance or having a place to go for care when sick or injured. ${ }^{18}$ Therefore, the excess non-fatal medically attended injury rat in whites and groups of higher socioeconomic status may partially reflect a greater access to medical care rather than more frequent occui rence of injuries.

Overpeck and Kotch reported that medical attended injury rates were between 30 to $40 \%$ lower for children without health care coverage (health insurance or Medicaid) than for chif dren with coverage. ${ }^{19}$ The latter analysis dis not address variations in injury rates that may be associated with the socioeconomic status and/or race factors affecting differential exposures such as occurrence at home or school. ${ }^{2}$ In 
this analysis, injury rates are analyzed by severity to control for confounding effects from care seeking behavior. Selected injury locations and causes are also addressed to describe the environment and contextual information needed to begin to address modifiable risk factors for prevention.

\section{Methods}

\section{SURVEY DESIGN}

The NHIS uses a multistage probability sample design of households, resulting in a representative sample of the US civilian noninstitutionalized population. In 1988 , one child under 18 years of age was selected from each family with children, resulting in a sample of 17110 children and an overall NHIS-CHS response rate of $91 \% .{ }^{20}$ Final weights adjusted for non-response are applied to all data in the analysis to reflect the injury experience of 64 million US children in this age group.

\section{VARIABLES}

Respondents, usually the mother, reported the nature, cause, and severity of each injury event occurring during the previous 12 months that resulted in medical attention. After classification to International Classification of Diseases external causes ( $\mathrm{E}$ codes), injuries resulting from medical misadventure or complications (E codes 929-949 and 870-879) are excluded.

Besides total medically attended injury rates, injuries are analyzed by subsequent effect. Injuries are considered to be 'consequential' if they resulted in at least one of the following effects: at least one bed day or lost school day, hospitalization, or surgery (including bone setting and stitches). Consequential injuries are analyzed separately to address the differences in propensity to seek care. Consequential injuries comprised $36 \%$ of the total. All other injuries are considered minor and are included in totals.

Analysis of causes and locations are limited to categories that occurred in large enough frequencies to produce valid estimates: injuries

Table 1 Distribution of socioeconomic status and racial/ethnic characteristics by access to care, US, 1988

\begin{tabular}{|c|c|c|c|}
\hline \multirow[b]{2}{*}{ Factor } & \multirow[b]{2}{*}{$\%(95 \% C I)$} & \multicolumn{2}{|c|}{ Access to care $(95 \% \mathrm{CI})$} \\
\hline & & $\%$ without coverage & \% without care place \\
\hline $\begin{array}{l}\text { Sample No } \\
\text { US population } \\
\% \text { US total } \\
\text { Adults in home }\end{array}$ & $\begin{array}{l}17110 \\
63539000 \\
100.0\end{array}$ & $\begin{array}{l}2865 \\
10757000 \\
16.9(16.1 \text { to } 17.8)\end{array}$ & $\begin{array}{l}1086 \\
4130000 \\
6.5(6.0 \text { to } 6.3)\end{array}$ \\
\hline $\begin{array}{l}1 \\
2 \\
\geqslant 3 \\
\text { No of children }\end{array}$ & $\begin{array}{l}16.4(15.6 \text { to } 17.2) \\
69.2(68.2 \text { to } 70.2) \\
14.3(13.7 \text { to } 14.9)\end{array}$ & $\begin{array}{l}19.3(17.5 \text { to } 21.1) \\
15.2(14.3 \text { to } 16.1) \\
22.6(20.5 \text { to } 24.7)\end{array}$ & $\begin{array}{l}7.8(6.6 \text { to } 9.0) \\
5.6(5.0 \text { to } 6.1) \\
9.6(8.2 \text { to } 11.0)\end{array}$ \\
\hline $\begin{array}{l}1 \geqslant-2 \\
\text { Maternal education } \\
\text { (years) }\end{array}$ & $\begin{array}{l}62.2(61.5 \text { to } 63.9) \\
37.8(36.6 \text { to } 39.0)\end{array}$ & $\begin{array}{l}16.0(15.4 \text { to } 16.6) \\
18.4(17.7 \text { to } 19.1)\end{array}$ & $\begin{array}{l}5.9(5.4 \text { to } 6.4) \\
7.5(6.5 \text { to } 8.5)\end{array}$ \\
\hline $\begin{array}{l}<12 \\
12 \\
>12 \\
\text { In poverty }\end{array}$ & $\begin{array}{l}21.8(20.9 \text { to } 22.8) \\
42.1(41.1 \text { to } 43.1) \\
36.0 \text { (35.0 to } 37.1)\end{array}$ & $\begin{array}{l}28.7(26.5 \text { to } 30.9) \\
15.8(14.7 \text { to } 16.9) \\
11.3(10.5 \text { to } 12.1)\end{array}$ & $\begin{array}{l}11.4(10.0 \text { to } 12.8) \\
6.0(5.2 \text { to } 6.8) \\
4.2(3.7 \text { to } 4.7)\end{array}$ \\
\hline $\begin{array}{l}\text { Yes } \\
\text { No }\end{array}$ & $\begin{array}{l}22.1(21.0 \text { to } 23.2) \\
77.9(76.8 \text { to } 79.0)\end{array}$ & $\begin{array}{l}29.7(27.5 \text { to } 31.9) \\
13.3(12.5 \text { to } 14.0)\end{array}$ & $\begin{array}{l}11.8(10.4 \text { to } 13.1) \\
5.0(4.6 \text { to } 5.5)\end{array}$ \\
\hline $\begin{array}{l}\text { Race/ethnicity } \\
\text { Non-Hispanic white } \\
\text { Non-Hispanic black } \\
\text { Mexican-American }\end{array}$ & $\begin{array}{l}70.2(68.7 \text { to } 71.7) \\
15.0(13.7 \text { to } 16.3) \\
7.0(6.2 \text { to } 7.8)\end{array}$ & $\begin{array}{l}14.1(13.3 \text { to } 14.9) \\
19.2(16.9 \text { to } 21.5) \\
36.1(32.2 \text { to } 40.0)\end{array}$ & $\begin{array}{l}5.0(4.4 \text { to } 5.5) \\
8.3(6.9 \text { to } 9.6) \\
14.8(11.7 \text { to } 17.9)\end{array}$ \\
\hline
\end{tabular}

due to falls and being struck or cut, or occurring at school and home. The findings by cause are not shown separately but are discussed when significant differences are found.

Race and ethnicity are self reported in the NHIS. Categories are limited to non-Hispanic blacks or whites, and to Mexican-Americans (Mexicans) due to the small numbers for other races or Hispanics. Total estimates include all racial/ethnic categories.

Assessed socioeconomic and demographic variables include access to care, maternal education, number of adults in the household, number of children, urbanicity of place of residence, age, sex, and poverty level. The latter is based on poverty guidelines developed as an official US index measuring effective family income by a ratio of income and family size. ${ }^{21}$ Years of maternal education are grouped in three levels with the unknown level included with the $<12$ years category. Coverage (health insurance or Medicaid) and having a place to go for care when sick or injured are analyzed separately and in combination because they measure two separate components of overall access.

\section{ANALYSIS}

Univariate statistics show whether each socioeconomic status variable is consistently associated with injury rates. Linear regression analyses are used to determine whether health care coverage affects injury rates for each socioeconomic status factor differently. Finally, regression analyses are used to determine the association of each socioeconomic status variable with injury rates after controlling for the effects of health care coverage and other factors.

Significant associations and interactions with injury rates are assessed using the REGRESS modeling procedure of SUDAAN (Software for Survey Data Analysis) ${ }^{22}$ with a backward stepwise approach. The standard error (SE) and confidence interval (CI) are appropriate for complex survey variance with asymmetrical cumulative incidence ratios and outcomes based on means of multiple event outcomes. $^{22-24}$ All CIs shown are at the $95 \%$ probability level. Rate ratios adjusted for the covariates are obtained by standardizing all covariate means to zero.

Age and sex are significant in the regression models and are kept to adjust for effect on the outcome but are not analyzed separately. Urbanicity of place of residence is not kept in the analysis due to lack of significant effect. All other variable effects are shown.

\section{Results}

The total US distribution by access to care for socioeconomic status and racial/ethnic groupings shows that the per cent of children without health care coverage or a place to go for care varies greatly across groups (table 1). Those with high maternal education levels, two adults in the household, or non-Hispanic whites are most likely to have either coverage or a place for care when injured. About $17 \%$ of the total 
population have no coverage, ranging from $11.3 \%$ of children whose mothers have more than 12 years of education to $36.1 \%$ of Mexicans. Only $6.5 \%$ have no place for care with Mexican children least likely to have a place to go $(14.8 \%)$. Overall, only $2.5 \%$ have neither coverage nor a place to go for care. Of the $16 \%$ of children living in single adult homes, $37 \%$ have a mother with $<12$ years of education and $52 \%$ live below the poverty level (data not shown).

Rates of injuries for children without coverage or with no care place are lower than for those with coverage (table 2). While number of adults in the household, maternal education, poverty level, race/ethnic status, and health care coverage are highly related, the injury rates for these socioeconomic status variables do not follow the same pattern. Injury rates are higher for children from single adult homes compared with homes with two or more adults, with the exception of injuries occurring at school. Children of mothers with the lowest

Table 2 Rates of non-fatal medically attended injuries in children by socioeconomic factor for selected injury categories, US, 1988

\begin{tabular}{|c|c|c|c|c|}
\hline $\begin{array}{l}\text { Socioeconomic } \\
\text { factor }\end{array}$ & $\begin{array}{l}\text { Total } \\
(95 \% \text { CI })\end{array}$ & $\begin{array}{l}\text { Consequential } \\
(95 \% \mathrm{CI})\end{array}$ & $\begin{array}{l}\text { Home } \\
(95 \% \text { CI) }\end{array}$ & $\begin{array}{l}\text { School } \\
\text { (95\% CI) }\end{array}$ \\
\hline $\begin{array}{l}\text { Coverage } \\
\text { None } \\
\text { Any }\end{array}$ & $\begin{array}{l}11.1(9.5 \text { to } 12.7) \\
17.3(16.4 \text { to } 18.2)\end{array}$ & $\begin{array}{l}3.6(2.7 \text { to } 4.5) \\
6.3(5.7 \text { to } 6.9)\end{array}$ & $\begin{array}{l}4.9(3.9 \text { to } 5.9) \\
7.6(6.9 \text { to } 8.5)\end{array}$ & $\begin{array}{l}2.4(1.7 \text { to } 3.1) \\
3.1(2.7 \text { to } 3.5)\end{array}$ \\
\hline $\begin{array}{l}\text { Care place } \\
\text { No place } \\
\text { A place } \\
\text { Adults in home }\end{array}$ & $\begin{array}{l}9.8(7.4 \text { to } 12.2) \\
16.7 \text { (15.9 to } 17.5)\end{array}$ & $\begin{array}{l}3.0(2.9 \text { to } 3.1) \\
6.0(5.4 \text { to } 6.6)\end{array}$ & $\begin{array}{l}4.0(2.4 \text { to } 5.6) \\
7.4(6.8 \text { to } 8.0)\end{array}$ & $\begin{array}{l}2.5(1.4 \text { to } 3.6) \\
3.0(2.7 \text { to } 3.3)\end{array}$ \\
\hline $\begin{array}{l}\text { Adults in home } \\
1 \\
2 \\
\geqslant 3\end{array}$ & $\begin{array}{l}18.9(16.7 \text { to } 21.1) \\
15.9(15.0 \text { to } 16.8) \\
15.0(12.8 \text { to } 17.2)\end{array}$ & $\begin{array}{l}6.9(5.6 \text { to } 8.2) \\
5.7(5.0 \text { to } 6.4) \\
5.3(4.0 \text { to } 6.6)\end{array}$ & $\begin{array}{l}8.5(7.2 \text { to } 9.8) \\
7.3(6.7 \text { to } 7.9) \\
5.1(3.7 \text { to } 6.5)\end{array}$ & $\begin{array}{l}2.7(1.9 \text { to } 3.5) \\
2.8(2.4 \text { to } 3.2) \\
4.1(3.1 \text { to } 5.1)\end{array}$ \\
\hline $\begin{array}{l}\text { No of children } \\
\quad 1-2 \\
\text { Mother's }\end{array}$ & $\begin{array}{l}16.4(15.5 \text { to } 17.3) \\
16.0(14.5 \text { to } 17.5)\end{array}$ & $\begin{array}{l}5.8(5.3 \text { to } 6.3) \\
5.9(4.8 \text { to } 7.0)\end{array}$ & $\begin{array}{l}7.0(6.4 \text { to } 7.6) \\
7.5(6.4 \text { to } 8.6)\end{array}$ & $\begin{array}{l}3.1(2.7 \text { to } 3.5) \\
2.9(2.3 \text { to } 3.5)\end{array}$ \\
\hline $\begin{array}{l}\text { education (years) } \\
\quad<12 \\
12 \\
>12 \\
\text { In poverty }\end{array}$ & $\begin{array}{l}12.7(11.0 \text { to } 14.4) \\
16.1(14.8 \text { to } 17.4) \\
18.6(16.7 \text { to } 21.1)\end{array}$ & $\begin{array}{l}4.5(3.6 \text { to } 5.4) \\
6.1(5.3 \text { to } 6.9) \\
6.2(5.3 \text { to } 7.1)\end{array}$ & $\begin{array}{l}6.2(5.1 \text { to } 7.3) \\
7.4(6.5 \text { to } 8.3) \\
7.6(6.7 \text { to } 8.5)\end{array}$ & $\begin{array}{l}2.2(1.5 \text { to } 2.8) \\
2.9(2.4 \text { to } 3.4) \\
3.7(3.1 \text { to } 4.3)\end{array}$ \\
\hline $\begin{array}{l}\text { Yes } \\
\text { No }\end{array}$ & $\begin{array}{l}13.5(11.9 \text { to } 15.2) \\
17.1(16.2 \text { to } 17.9)\end{array}$ & $\begin{array}{l}5.1(4.2 \text { to } 6.1) \\
6.0(5.4 \text { to } 6.6)\end{array}$ & $\begin{array}{l}7.0(5.8 \text { to } 8.2) \\
7.2(6.6 \text { to } 7.8)\end{array}$ & $\begin{array}{l}1.8(1.2 \text { to } 2.4) \\
3.3(2.9 \text { to } 3.7)\end{array}$ \\
\hline $\begin{array}{l}\text { Race/ethnicity } \\
\text { Non-Hispanic white } \\
\text { Non-Hispanic black } \\
\text { Mexican-American }\end{array}$ & $\begin{array}{l}19.2(18.2 \text { to } 20.1) \\
9.1(7.9 \text { to } 10.3) \\
10.6(7.8 \text { to } 13.5)\end{array}$ & $\begin{array}{l}7.1(6.4 \text { to } 7.8) \\
3.0(2.3 \text { to } 3.7) \\
2.4(1.0 \text { to } 3.7)\end{array}$ & $\begin{array}{l}8.4(7.8 \text { to } 9.0) \\
3.9(2.8 \text { to } 4.9) \\
6.3(3.9 \text { to } 8.6)\end{array}$ & $\begin{array}{l}3.5(3.1 \text { to } 3.9) \\
1.8(1.2 \text { to } 2.4) \\
2.0(0.6 \text { to } 3.4)\end{array}$ \\
\hline Total rates & 16.3 (15.5 to 17.0$)$ & $5.8(5.3$ to 6.4$)$ & $4.1(3.7$ to 4.5$)$ & 3.8 (3.4 to 4.2$)$ \\
\hline
\end{tabular}

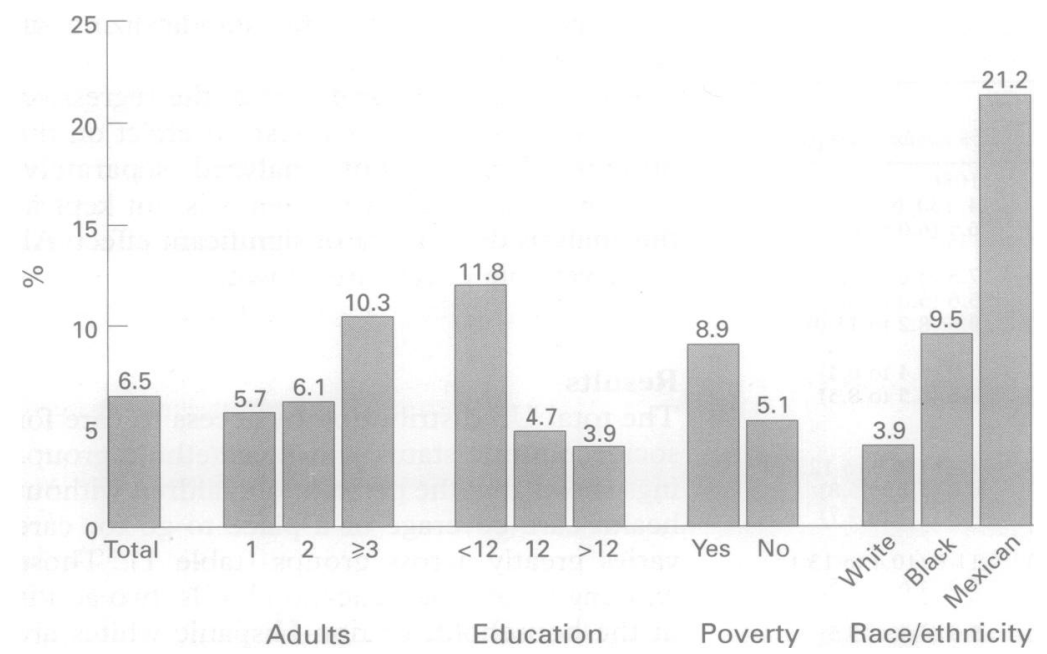

Figure 1 Per cent increase in medically attended injury rates if all children had health care coverage. education levels and those in poverty tend to have fewer medically attended injuries compared with those in the highest maternal education levels or those above the poverty

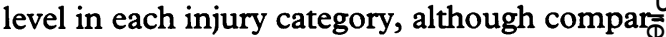
isons are not always significantly different. Rates are lower for blacks and Mexicans tha $\vec{f}$ whites in all injury categories.

Because consequential injuries represent les than half of all medically attended injurie reported, the total rates are predominately $\overline{\mathbf{6}}$ reflection of minor injuries. The associations with access, socioeconomic status, and racial? ethnic factors were similar for total, conse quential, and minor injury categories. (Mino $\vec{f}$ injuries are not shown.)

The figure shows per cent increases in tot injury rates across the socioeconomic statu and race/ethnicity categories that would occuio if all children had coverage (insurance ox Medicaid). The largest increases are fof Mexicans, blacks, maternal education $<12$ years, three or more adults in the home, an those living below poverty level.

Ratios for total injury rates were adjusted to determine the effect of access to care on the inconsistent comparisons by socioeconomi status or race/ethnicity (table 3). Adjustmerif for access to care alone (column 2) increases each unadjusted ratio, slightly but not signiff cantly.

Of the two components used to measun access, coverage makes the greatest contribu影 tion. Having coverage lessens the discrepancy in injury rate ratios for those with or without place to go for care (columns 1 and 2 \& Adjusting coverage for having a place to go for care has essentially no effect, consistenit with underlying distributions (table 1).

Since the distributions of each socioeco nomic status categorical level and racial/ethnis group vary across the factors and may bo measuring similar underlying risk attributes. the associations with injury are evaluated by adjusting the association of each individua factor for the effect of the other factors (column 3). The adjustments have the effee of increasing each rate ratio estimate, except for the comparison between blacks and whites. However, none of the increases are signif cantly different from the crude associations except for poverty, as shown by the CIs. The ratios for poverty increase from 0.79 (CI 0.68 to 0.91 ) to 1.04 (CI 0.92 to 1.16 ) indicating ne difference between those below or above the poverty level after adjusting for access to care maternal education, number of adults cis children in household, or race/ethnicity. Chiff dren in a household with a single adult stith have an increased risk of $40 \%$ after adjustmert for access to care and all other factors.

Results for the other injury categories (cor sequential, occurrence at home or school, and the two causes, falls and being struck or cut are consistent with those shown in table 3. The greater risk found for children in single aduft families is consistent across all injury categories except for those occurring at school (rate ratio (RR) 1.03 , CI 0.68 to 1.59 ). Risks for children in single adult families are increased by about 
Table 3 Total injury rate ratios (RR) by access to care (health insurance/Medicaid or place for care), socioeconomic status and raciallethnic factors, US, 1988

\begin{tabular}{|c|c|c|c|}
\hline Access factor & Unadjusted $R R(C I)$ & $\begin{array}{l}R R, \text { adjusted } \\
\text { for access to care }(C I)^{*}\end{array}$ & $\begin{array}{l}R R, \text { adjusted } \\
\text { for all factors (CI) } \dagger\end{array}$ \\
\hline \multicolumn{4}{|l|}{ Coverage } \\
\hline $\begin{array}{l}\text { No [yes] } \\
\text { Place for care if injured }\end{array}$ & $0.64(0.50$ to 0.80$)$ & $0.67^{\star}(0.58$ to 0.77$)$ & $0.76(0.66$ to 0.88$)$ \\
\hline Place for care if injured & 0.59 (0.35 to 0.83$)$ & $0.67^{\star}(0.54$ to 0.83$)$ & $0.69(0.55$ to 0.85$)$ \\
\hline \multicolumn{4}{|l|}{ No of adults } \\
\hline $\begin{array}{l}1[2] \\
\geqslant 3[2]\end{array}$ & $\begin{array}{l}1.19(1.06 \text { to } 1.32) \\
0.94(0.79 \text { to } 1.10)\end{array}$ & $\begin{array}{l}1.21(1.07 \text { to } 1.37) \\
0.99(0.92 \text { to } 1.06)\end{array}$ & $\begin{array}{l}1.40(1.24 \text { to } 1.58) \\
1.03(0.89 \text { to } 1.20)\end{array}$ \\
\hline \multicolumn{4}{|l|}{ No of children } \\
\hline \multicolumn{4}{|c|}{ Maternal education (years) } \\
\hline $\begin{array}{l}<12[>12] \\
12[>12]\end{array}$ & $\begin{array}{l}0.68(0.53 \text { to } 0.83) \\
0.87(0.76 \text { to } 0.98)\end{array}$ & $\begin{array}{l}0.74(0.64 \text { to } 0.86) \\
0.89(0.79 \text { to } 0.99)\end{array}$ & $\begin{array}{l}0.75(0.65 \text { to } 0.87) \\
0.87(0.78 \text { to } 0.97)\end{array}$ \\
\hline \multicolumn{4}{|l|}{ In poverty } \\
\hline \multicolumn{4}{|l|}{ Race/ethnicity } \\
\hline $\begin{array}{l}\text { Black [white] } \\
\text { Mexican-American }\end{array}$ & $0.47(0.41$ to 0.54$)$ & $0.49(0.43$ to 0.56$)$ & $0.43(0.36$ to 0.53$)$ \\
\hline [white] & $0.55(0.42$ to 0.73$)$ & 0.63 (0.49 to 0.81$)$ & $0.67(0.53$ to 0.85$)$ \\
\hline
\end{tabular}

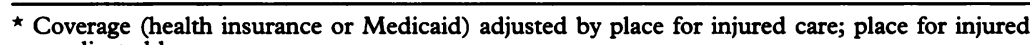

care adjusted by coverage. t Adjusted for coverage, place for care,
household, age, sex, and race/ethnicity.

[ ] =reference group. official poverty status. We also found increased rates associated with use of Medicaid in this and another study. ${ }^{19}$ Part of the difference may be that the types of injuries occurring to children living in poor, non-supportive environments are more likely to lead to severe outcomes resulting in hospitalization and death.

Limitations of this study include the small number and imprecision of socioeconomic status and racial/ethnic measures available in the NHIS that may be related to injury determinants. Low maternal education levels may function as a proxy for other factors such as early childbearing that are highly correlated with poverty and neighborhood effects. Neighborhood data were not available but also have been shown to be an injury risk factor. ${ }^{11-1333-35}$ Another limitation is that these analyses focused on total and consequential medically attended injuries rather than on more cause specific exposures (for example motor vehicles, bicycles) due to small numbers.

This analysis has a number of methodological implications. First, analysis of data from provider sources should take into account the socioeconomic status and health care coverage distributions of the population studied. ${ }^{18202836}$ For example, we estimate that after adjustment for loss due to recall, ${ }^{37}$ an additional 131000 black and 161000 Mexican children would have received medical attention for injuries if all children had coverage. Second, detailed measures of barriers to seeking care would provide much needed information on the components of access to care limiting medical attention for injuries. Third, the data show that research using only the poorly measured racial and/or ethnic identifiers on death certificates, without additional risk factor information (besides age and sex) may result in incorrect inferences. ${ }^{38} 39$ Misleading associations of cultural and residential factors with race and/or ethnicity have been noted by other researchers, leaving unanswered questions on what race and ethnicity are actually measuring. ${ }^{40} 44$

Almost two thirds of the medically attended injuries in this survey are classified as minor. However, consistency in the results comparing total and consequential injuries indicates that differences associated with access probably are not due entirely to care seeking factors. Some of the increased rates associated with higher socioeconomic status may be due to greater exposure to risk factors such as bicycles, sports, or recreation activities which are usually minor and represent $36 \%$ of these injuries at ages 5$17 .{ }^{43}$ Children in families with lower socioeconomic status may spend equivalent time in lower risk activities, such as watching TV. ${ }^{44}$

Having a single adult in the household increases the risk of a non-fatal injury by $40 \%$ compared with homes with two or more adults. This finding is consistent across all categories of injury except for those occurring at school, reinforcing effects from single adult home environments. A Scottish study of adolescents found similar differences by location with increased injuries at home predicted by low family affluence and injuries at school predicted by high affluence and sports participafamily size. ${ }^{21}$ Others have used income ${ }^{911}$ or participation in social welfare programs, such as Aid to Families with Dependent Children, Food Stamps or Medicaid, ${ }^{12}$ directly linked to 
tion. ${ }^{45}$ Single adult households might be at greater risk due to various environmental, traffic, or housing characteristics that are also associated with poor neighborhoods. ${ }^{33} 34$

In addition, single parenting is highly associated with earlier initiation of childbearing leading to incomplete education, presence of non-related adults in the homes, and potentially lower 'locus of control'. The latter may affect the ability to provide either a protective physical or social environment. ${ }^{1346}$ Early intervention through nurse home visitation from the prenatal period through early childhood has shown improved child health and injury outcomes with adolescent single parents. ${ }^{47}$

This is the first US study to obtain population characteristics for all medically attended non-fatal injuries in children. Because it incorporates injuries treated in all health care settings with information on severity, cause, location, and other data, the portrait of injuries in children is far different from the portrait based on fatality data or from hospital and emergency room records. This study suggests that some US children are at risk of injury from factors associated with affluence, while others are at risk from underlying exposures stemming from inadequate housing, neighborhoods, or protective families. This is why access to care accounts for only a portion of the higher rates of medically attended injuries for some children. Studies of activities and injury locations associated with socioeconomic status are needed to address injury prevention. Adding more complete information to injury data sources about specific contributing components will improve the focus of future research and interventions.

1 Wagner DK, Winn DW. Injuries in working populations: black-white differences. Am f Public Health 1991; 81: $1408-14$.

2 Scheidt PC, Harel Y, Trumble AC, Jones DH, Overpeck $M D$, Bijur PE. The epidemiology of non-fatal injuries in children and youth. Am $\mathcal{F}$ Public Health 1995; 85: 932-8.

3 Kogan MD, Overpeck MD, Fingerhut LA. Medicallyattended nonfatal injuries among preschool age children: national estimates. Am ₹ Prev Med 1995; 11: 99-104.

4 Ries PW. Health of black and white Americans, 1985-87. National Center for Health Statistics. Vital Health Stat 10(171) 1990.

5 Bijur PE, Kurzon M, Overpeck MD, Scheidt PC. Parental alcohol use, problem drinking, and children's injuries. FAMA 1992; 267: 3166-71.

6 McCaig LF, Graitcer PL. Epidemiology of injury-related visits to office-based physicians in the United States, 1991. Fournal of Safety Research 1994; 25: 77-81.

7 Benson V, Marano MA. Current estimates from the National Health Interview Survey, 1993. National Center for Health Statistics. Vital Health Stat 10(190), 1995.

- 8 National Center for Health Statistics. Health, United States, 1993. Hyattsville, MD: Public Health Service, 1994: 25-

9 Baker SP, O'Neill B, Ginsburg MJ, Li G. The injury fact book. 2nd Ed. New York, NY: Oxford University Press, 1992: $25-50$.

10 National Committee for Injury Prevention and Control. Injury prevention: meeting the challenge. New York, NY: Oxford University Press, 1989: 35-42.

11 Durkin MS, Davidson LL, Kuhn L, O'Connor P, Barlow B. Low-income neighborhoods and the risk of severe pediatric injury: a small-area analysis in northern Manhattan. Am $\mathcal{F}$ Public Health 1994; 84: 587-92.

12 Nersesian WS, Petit MR, Shaper R, Lemieus D, Naor E. Childhood death and poverty: a study of all childhood deaths in Maine, 1976-1980. Pediatrics 1985; 75: 41-50.

13 Winpisinger KA, Hopkins RS, Indian RW, Hostetler JR. Risk factors for childhood homicides in Ohio: a birth certificate-based case-control study. Am 7 Public Health 1991; 81: 1052-4.

14 Anderson R, Dearwater SR, Olsen T, et al. The role of socioeconomic status and injury morbidity risk in adolescents. Arch Pediatr Adolesc Med 1994; 148: 245-9.

15 Langley J, Silva P, Williams S. Socioeconomic status and childhood injuries. Aust Paediatr f 1983; 19: 237-40.

16 Manheimer DI, Dewey J, Mellinger GD, Corsa L Jr. 50,000 child-years of accidental injuries. Public Health Rep 1966; 81: $519-33$.

17 King A, Wold B, Tudor-Smith C, Harel Y. The health of youth. a cross-national survey. Copenhagen Denmart. youth: a cross-national survey. Copenhagen, Den

18 Newacheck PW, Hughes DC, Stoddard JJ. Children' access to primary care: differences by race, income, and insurance status. Pediatrics 1996; 97: 26-32.

19 Overpeck MD, Kotch JB. Effect of US children's access to care on medical attention for injuries. Am $\mathcal{f}$ Public Healt 1995; 85: $402-4$.

20 National Center for Health Statistics. Current estimates fron the National Health Interview Survey, 1988. DHHक Publication No (PHS) 89-1501. Washington, DC Government Printing Office, October 1989.

21 Fisher GM. Poverty guidelines for 1992: a background paper on poverty guidelines. Social Security Bulletin Spring 1992; 55(1): $43-6$

22 Research Triangle Institute. Software for survey data analys $\vec{\rho}$ (SUDAAN). Version 6.30. Research Triangle Park, NCResearch Triangle Institute, 1991.

23 Katz D, Baptista J, Azen SP, Pike MC. Obtaining confidence intervals for the risk ratio in cohort studiesBiometrics 1978; 34: 469-74.

24 Kleinbaum DG, Kupper LL, Morgenstern H. Epidemiologic research. Belmont, CA: Lifetime Learning Publicationsis 1982: 298.

25 Valdez RB, Ware JE, Manning WG, et al. Prepaid group practice effects on the utilization of medical services and practice effects on the utilization of medical services and health outcomes for children: result

26 Kogan MD, Alexander GR, Teitelbaum MA, Jack BWD Kotelchuck M, Pappas G. The effect of gaps in healti insurance on continuity of a regular source of care among preschool-age children in the United States. FAMA 1995: 274: 1429-35.

27 Lohr KN, Brook RH, Kamberg CJ, et al. Use of medicaP care in the Rand health insurance experiment: diagnosisand service-specific analyses in a randomized controlledo trial. Med Care 1986; 24:(9,suppl): S1-36.

28 Lillie-Blanton M, Alfaro-Correa A. In the nation's interest: equity in access to health care. Washington, DC: Joing equity in access to health care. Washington, DC: Joing $12-22$.

29 Cornelius LJ. Barriers to medical care for white, black, an Hispanic American children. F Natl Med Assoc 1993; 85, $281-8$.

30 Lucas CA, Rosenthal TC. Access to health care in rurab western New York State. NY State fMed 1992; 92: 465-9

31 James S. John Henryism and the health of Africane Americans. Cult Med Psychiatry 1994; 18: 163-82.

32 Kalmuss D, Fennelly K. Barriers to prenatal care among low-income women in New York City. Fam Plann Perspect 1990; 22: $215-8$.

33 McLoughlin E, McGuire A. The causes, cost and preven tion of childhood burn injuries. Am $\mathcal{F}$ Dis Child 1990; 144. tion of child $677-83$.

34 Mueller BA, Rivara FP, Lii SM, Weiss NS. Environment factors and the risk for childhood pedestrian-moto vehicle collision occurrence. Am f Epidemiol 1990; 132 $550-60$.

35 Nelson MD Jr. Socioeconomic status and childhooळ mortality in North Carolina. Am $\mathcal{f}$ Public Health 1992 83: $1131-3$.

36 Overpeck MD, Kotch JB, Trumble AC. Effects of materna education and access to medical care on analysis of injury risk according to patterns of child care. Proceedings of thi 1993 public health conference on records and statistic Hyattsville, MD: DHHS Publication No (PHS) 94-3 1214: $67-72$.

37 Harel Y, Overpeck MD, Jones DH, et al. Effects of recall o온 estimating annual non-fatal injury rates for children and youth. Am f Public Health 1994; 84: 599-605.

$38 \mathrm{Hahn} \mathrm{RA}$. Inconsistencies in coding of race and ethnicit between birth and death in US infants: a new look at infant mortality, 1973-1985. fAMA 1992; 167: 259-63U

39 Hahn RA, Stroup DF. Race and ethnicity in public health surveillance: criteria for the scientific use of socias categories. Public Health Rep 1994; 109: 7-15.

40 Cooper RS. A case study in the use of race and ethnicity in public health surveillance. Public Health Rep 1994; 109 46-52.

41 LaVeist TA. Beyond dummy variables and sample selection what health services researchers ought to know about rac what health services researchers ought to know about races

42 Polednak AP. Racial and ethnic differences in disease. New York, NY: Oxford University Press, 1989: 274.

43 Bijur PE, Trumble AC, Harel Y, et al. Sports and recreation injuries in US children and adolescents. Arch Pediagh Adolesc Med 1995; 149: 1009-16.

44 Comstock G, Paik H. Television and the American child. Sa® Diego, CA: Academic Press, 1991: 69-75.

45 Williams JM, Currie CE, Wright P, Elton RA, Beattie FT? Socioeconomic status and adolescent injuries. Soc $S \&$ Med 1997; 44: 1881-91.

46 Menaghan EG, Parcel TL. Determining children's home environments: the impact of maternal characteristics and current occupational and family conditions. fournal of Marriage and the Family 1991; 53: 417-31.

47 Olds DL, Henderson CR, Kitzman H. Does prenatal and infancy home visitation have enduring effects on qualities of parental caregiving and child health at 25 and 50 months of life? Pediatrics 1994; 93: 89-98. 